\title{
Peran Mahkamah Konstitusi Dalam Penegakan Hukum Konstitusi
}

\author{
Maruarar Siahaan \\ Mahkamah Konstitusi Jl. Medan Merdeka Barat No. 6 Jakarta
}

\begin{abstract}
The enforcement of constitutional law as stated in the authority of the Indonesian Constitutional Court may will run effectively in the form of equal horizontal-functional based on the doctrine of checks and balances in the separation of power, when the verdict issued by this constitutional court is accepted and implemented by the concerned parties. The Indonesian Constitutional Court may safeguard their verdicts in the form of Conditional Constitutionality and Grace Period in order to implement the verdict which states whether an act in unconstitutional, however this cannot guarantee that the constitutional law will run. All related aspects are actually subject to the political-will of the government (executives) and legislators (law makers).
\end{abstract}

Keywords: the constitution court, law enforcement

\section{Pendahuluan}

Reformasi yang menghasilkan empat kali perubahan UUD 1945 telah membawa nuansa baru dalam sistem ketatanegaraan Indonesia. Sistem yang diadopsi sesungguhnya merupakan sesuatu yang sangat baru bagi Indonesia dalam arti lahirnya pembagian kekuasaan secara horizontal fungsional menggantikan bentuk yang vertikal hirarkis, dengan Majelis Permusyawaratan Rakyat sebagai lembaga negara tertinggi berada di puncak kekuasaan. Dengan pergeseran ke arah penyusunan kekuasaan yang bersifat horizontal fungsional tersebut, maka kedudukan lembagalembaga negara menjadi setara, yang masing-masing secara fungsional melakukan pengawasan terhadap lembaga negara lain sebagai penyelenggara kekuasaan negara. Perubahan yang dilakukan bertujuan antara lain untuk menyempurnakan aturan dasar penyelenggaraan 
negara secara demokratis dan modern, antara lain melalui pembagian kekuasaan yang lebih tegas, sistem checks and balances yang lebih ketat dan transparan, dan pembentukan lembaga-lembaga negara yang baru untuk mengakomodasi perkembangan kebutuhan bangsa dan tantangan zaman. ${ }^{1}$

Kedaulatan rakyat yang berada di tangan rakyat, tadinya dilakukan sepenuhnya oleh Majelis Permusyawaratan Rakyat, dengan perubahan ketiga kedaulatan rakyat tersebut kemudian dilaksanakan menurut Undang-Undang Dasar. ${ }^{2}$ Pernyataan bahwa Indonesia ialah negara yang berdasarkan hukum(rechtsstaat) dan tidak berdasarkan kekuasaan belaka (machtsstaat), yang semula termuat dalam Penjelasan UUD 1945 sebelum perubahan, telah dimuat menjadi materi Undang-Undang Dasar 1945 Perubahan. ${ }^{3}$ Dengan perubahan tersebut, maka terjadi pergeseran dari sistem supremasi parlemen, dimana MPR merupakan lembaga tertinggi negara menjadi sistem dengan supremasi konstitusi, dimana Konstitusi ditempatkan sebagai hukum yang tertinggi, yang menjadi sumber legitimasi dari peraturan perundang-undangan yang dibentuk dan berlaku. Pernyataan bahwa kedaulatan ditangan rakyat yang dilaksanakan berdasarkan Undang-Undang Dasar serta pernyataan bahwa Negara Indonesia adalah negara hukum, merupakan pendirian yang tegas bahwa prinsip penyelenggaraan negara secara demokratis yang didasarkan pada konstitusi (constitutional democracy) dan negara hukum yang dianut bersisfat demokratis (democratische rechtsstaat). Terdapat tiga ciri utama yang menandai prinsip supremasi konstitusi, yaitu (i) pembedaan antara norma hukum konstitusi dan norma hukum yang lainnya, (ii) terikatnya pembuat undang-undang oleh undang-undang dasar, dan (iii) adanya satu lembaga yang memiliki kewenangan untuk

\footnotetext{
${ }^{1}$ Panduan Dalam Memasyarakatkan Undang-Undang Dasar Negara Republik Indonesia Tahun 1945, Latar Belakang, Proses Dan Hasil Perubahan Undang-Undang Dasar Negara Republik Indonesia Tahnun 1945, Sekretariat Jenderal MPR R.I. 2003, hlm. 16.

${ }^{2}$ Pasal 1 Ayat (2) Undang-Undang Dasar 1945 Perubahan.

${ }^{3}$ Pasal 1 Ayat (3) Undang-Undang Dasar 1945 Perubahan. Ditengah proses pembahasan perubahan Undang-Undang Dasar 1945, Panitia Ad Hoc I menyusun kesepakatan dasar berkaitan dengan perubahan yang akan dilakukan, yang mencakup lima hal,antara lain tidak akan dilakukan perubahan atas Pembukaan Undang-Undang Dasar 1945, dan meniadakan penjelasan UUD 1945 tersebut, tetapi memasukkan hal-hal normatif dalam Penjelasan menjadi bagian dari batang tubuh dalam pasal-pasal. (Panduan Dalam Memasyarakatkan Undang-Undang Dasar Negara NegaraRepublik Indonesia Tahiun 1945, Op. Cit., hlm 25.)
} 
menguji konstitusionalitas tindakan hukum Pemerintah atau pembentuk UU. ${ }^{4}$

Pengujian undang-undang yang dilakukan dalam satu peradilan, yang lazim disebut dengan judicial review, yang diawali dengan sebuah permohonan, akan berakhir dalam satu putusan, yang merupakan pendapat tertulis hakim konstitusi tentang perselisihan penafsiran satu norma atau prinsip yang ada dalam UUD yang dikonkretisir dalam ketentuan undang-undang sebagai pelaksanaan tujuan bernegara yang diperintahkan konstitusi. Satu amar putusan yang mengabulkan satu permohonan pengujian, akan menyatakan satu pasal, ayat atau bagian dari undang-undang, dan bahkan undang-undang secara keseluruhan bertentangan dengan UUD 1945, yang kemudian sebagai konsekuensinya undang-undang, pasal, ayat atau bagian dari undang-undang yang diuji tidak lagi mempunyai kekuatan hukum mengikat. Bunyi putusan demikian mengandung arti bahwa ketentuan norma yang termuat dalam satu undang-undang dinyatakan batal (null and void) dan tidak berlaku lagi. Putusan yang demikian akan berdampak luas dan membutuhkan mekanisme prosedural tentang bagaimana tindak lanjut dari pembatalan pemberlakuan suatu ketentuan tersebut dan bagaimana pula mekanisme agar masyarakat dapat mengetahui bahwa norma tersebut tidak lagi berlaku. Dengan kewenangan judicial review demikian sesungguhnya telah turut menjadi policy maker melalui pengujian dan tafsir yang digunakan MK untuk penyelesaian perselisihan yang dihadapkan padanya. Hal demikian merupakan sesuatu yang dipandang paradoksal. Di satu sisi sistem politik dan pemerintahan didasarkan pada demokrasi, akan tetapi Hakim-hakim yang tidak dipilih secara demokratis-setidak-tidaknya sebagian dari mereka dapat membatalkan produk undang-undang, yang dibuat oleh wakil-wakil rakyat yang dipilih rakyat secara langsung. Hakim yang merupakan pejabat publik yang tidak dipilih oleh rakyat secara langsung tersebut telah menilai dan menguji produk dari wakil-wakil rakyat. Dengan kata lain mereka menguji output proses perumusan kebijakan yang demokratis, dari segi tugasnya untuk menjamin bahwa hukum tertinggi dipatuhi dengan setia oleh pembuat undang-undang, apakah perbuatannya konstitusional atau tidak. ${ }^{5}$

\footnotetext{
${ }^{4}$ Jutta Limbach, The Concept of the Supremacy of the Constitution, dalam The Modern Law Review Vol.64, No. 1, Januari 2001, hlm. 3.

${ }^{5}$ Howard Ball, Courts And Politics, The Federal Judicial System, Prentice-Hall Inc, Englewood Cliffs, N.J. 1980, 18. Lebih jauh ditulis, "These non-elected judges were examining
} 
Dalam tindak lanjut putusan MK yang membatalkan satu undangundang, baik pasal, ayat atau bagiannya saja, dibutuhkan kejelasan bagaimana implementasi putusan demikian dapat berlangsung efektif dalam koordinasi horizontal fungsional yang setara berdasar doktrin checks and balances dalam separation of powers. Secara juridis, meskipun hanya deklaratif, putusan MK dalam perkara pengujian undang-undang terhadap undang-undang dasar memiliki sifat konstitutif, baik berupa pembentukan norma hukum baru maupun yang meniadakan satu norma hukum dalam ketentuan undang-undang yang diuji. Dalam hal yang demikian, sebagaimana dikatakan Hans Kelsen, Hakim Mahkamah Konstitusi adalah negative legislator, yang melalui putusan-putusannya melaksanakan keseimbangan dalam penyelenggaraan kekuasaan negara. ${ }^{6}$ Dikatakannya bahwa: "The annulment of a law is legislative function, an act-so to speak - of negative legislation. A court which is competent to abolish laws - individually or generally - functions as a negative legislator". Keputusan demikian mengikat secara umum, sehingga semua organ penegak hukum, terutama pengadilan terikat untuk tidak menerapkan lagi hukum yang demikian. ${ }^{7}$ Kewenangan yang memberi kemungkinan bahwa satu undang-undang yang dihasilkan organ legislatif dapat dinyatakan tidak mempunyai kekuatan hukum mengikat, merupakan satu pembatasan yang luar biasa terhadap kekuasaan legislatif tersebut. Hal demikian disamping selalu dapat dipersoalkan dari segi prinsip-prinsip demokrasi

the actions of popularly elected officials to determine whether the actions were legitimate or whether the rights of other classes had been violated in the name of the people. And they were using as a standard of measurement the very instrument used by the policy makers to pass the acts in dispute : the Constitution".

${ }^{6}$ Hans Kelsen, General Theory of Law And State, New York, Russel \& Russel, 1973, hlm. 268 .

${ }^{7}$ Ada yang meragukan bahwa tidak disebutnya putusan MK bersifat final dan mengikat, melainkan hanya final sebagai putusan pada tingkat pertama dan terakhir, menyebabkan putusan final belum tentu dianggap mengikat oleh institusi-institusi diluar MK, sehingga para pejabat tidak terikat oleh putusan MK tersebut dan tidak wajib untuk melaksanakannya.(Achmad Syahrizal,Problematik Implementasi Putusan MK, Journal Konstitusi Volume 4 Nomor 1,Mart 2007, hlm 123). Pendapat tersebut kurang tepat, karena berdasarkan pasal 47 UU MK, putusan tingkat pertama dan terakhir yang final tersebut, memperoleh kekuatan hukum tetap sejak diucapkan dalam sidang terbuka untuk umum yang bersifat erga omnes, yaitu akibat hukumnya mengikat semua pihak, baik pihak dalam perkara maupun institusi negara lainnya. Kurangnya sosialisasi dan pemahaman akan akibat hukum yang timbul,lebih mungkin menjadi penyebab tidak dirasakannya implementasi tersebut merupakan kewajiban konstitusional. 
atas dasar mana anggota legislatif dipilih - sebagaimana telah disinggung di atas - yang putusannya dapat dikoreksi oleh Hakim MK yang tidak dipilih dan bekerja atas dasar prinsip yang berbeda, hemat kami hal demikian akan memiliki implikasi atas efektif tidaknya implementasi putusan MK tersebut. Rekonsiliasi atas antagonisme yang dapat terjadi diantara kedua cabang kekuasaan negara tersebut, akan berkembang secara dinamis ke satu arah konsep konstitusionalisme dan negara hukum (rule of law) Indonesia yang banyak tergantung kepada pemahaman dan penghayatan penyelenggara kekuasaan negara berdasar konstitusi.

\section{UUD 1945 sebagai Hukum Tertinggi}

Kedudukan UUD 1945 sebagai hukum yang tertinggi dalam negara hukum Indonesia, telah secara tegas ditetapkan sejak TAP MPRS nomor III/MPRS/1966. Kemudian dimuat pula dalam TAP MPR nomor III/ MPR/2000. Terakhir hal itu dimuat lagi dalam pasal 3 ayat (1) UndangUndang Nomor 10 tahun 2004 tentang Pembentukan Peraturan Perundang-Undangan, yang berbunyi “Undang-Undang Dasar Negara Republik Indonesia tahun 1945 merupakan hukum dasar dalam peraturan perundang-undangan". Konsekuensi kedudukan UUD 1945 sebagai hukum dasar yang merupakan hukum tertinggi, menyebabkan tidak diperkenankan adanya peraturan perundang-undangan yang bertentangan dengan hukum dasar tersebut, ${ }^{8}$ karena sistim konstitusi dalam dirinya mengandung pengujian konstitusional norma-norma yang dibentuk. Ketika timbul benturan antara aturan konstitusi dan aturan perundang-undangan yang lebih rendah, maka pejabat negara wajib terikat untuk menghormati aturan konstitusi dan mengesampingkan aturan perundang-undangan yang lebih rendah. Hal ini lahir dari prinsip bahwa setiap tindakan/perbuatan dan aturan perundang-undangan dari semua otoritas yang diberi wewenang oleh konstitusi, tidak boleh bertentangan dengan UUD sebagai hukum dasar atau hukum tertinggi, dengan konsekuensi bahwa aturan atau tindakan demikian dapat dibatalkan atau menjadi batal demi hukum, dan tidak mempunyai kekuatan hukum mengikat. Jika hal ini diingkari, maka peraturan perundang-undangan demikian akan menyangkal kedudukan UUD 1945 sebagai hukum dasar dan hukum tertinggi, yang sekaligus merupakan

\footnotetext{
${ }^{8}$ Pasal 7 UU No. 10/2004
} 
sumber kewenangan lembaga negara. ${ }^{9}$ Tafsir konstitusi merupakan wilayah yang tepat dan khas bagi Mahkamah. A constitution is, in fact, and must be regarded by the judges as, a fundamental law. It therefore belongs to them to ascertain meaning as well as the meaning of any particular act proceeding from the legislative body. If there should happen to be an irreconcilable variance between the two, that which has superior obligation and validity ought, of course, to be preferred; or in other words, the Constitution ought to be preferred to the statute, the intention of the people to the intentions of their agents. ${ }^{10}$

Masalah yang selalu dipersoalkan, berkaitan dengan fungsi Hakim menguji undang-undang kepada UUD, ialah persolan legitimasi, bagaimana penyelenggara kekuasaan eksekutif dan legislatif yang dipilih secara langsung oleh rakyat boleh diawasi dan dikontrol oleh Hakim MK yang tidak dipilih secara langsung oleh Rakyat. Apakah hal itu tidak bertentangan dengan demokrasi, dimana produk demokrasi dalam bentuk undang-undang yang dibuat dengan suara mayoritas dapat dibatalkan oleh 9 orang hakim yang tidak dipilih secara langsung oleh rakyat. Titik tolak pemikiran demikian merupakan faktor tersendiri yang kemungkinan ikut menyebabkan kesulitan dalam penerimaan putusan $\mathrm{MK}$, sehingga juga menjadi kendala dalam implementasi. Akan tetapi dengan kewenangan pembentuk undang-undang yang didasarkan pada proses politik dalam pengambilan keputusan dengan suara terbanyak, memang boleh jadi timbul kemungkinan bahwa keputusan yang diambil tidak menggambarkan amanat UUD 1945 yang juga melindungi hak asasi manusia, yang diinkorporasikan dalam konstitusi sehingga menjadi bagian dari tolok ukur dalam menilai produk legislatif. Namun tetap menjadi hambatan dalam implementasi putusan MK, terutama jika implementasinya membutuhkan revisi atas undang-undang yang telah diuji, atau menyangkut kebijakan maupun realokasi dana dalam anggaran belanja, yang kemungkinan karena alasan kepentingan sendiri, menimbulkan keengganan, ketidaksediaan untuk melaksanakan dan bahkan perlawanan untuk menolak pelaksanaannya yang berujung pada stagnasi.

Terlebih lagi pandangan yang mengatakan bahwa konstitusionalisasi hak asasi manusia yang bersifat sosial, ekonomi dan kebudayaan, dalam teori konstitusi juga dipandang merupakan faktor penyebab yang

\footnotetext{
${ }^{9}$ Alexander Hamilton, The Federalist Papers, Mentor Book, The New American Library, 1961, hlm. 467.

${ }^{10}$ Ibid.
} 
diperhitungkan dalam hambatan implementasi putusan MK, karena adanya pendapat bahwa hak sosial dan ekonomi demikian sesungguhnya merupakan positive rights, yang sifatnya lebih merupakan cita-cita, dan karenanya tidak dapat dilaksanakan melalui putusan pengadilan. ${ }^{11}$ Perdebatan tentang ini berpusat pada argumen apakah konstitusionalisasi hak sosial dan ekonomi memiliki implikasi pada legitimasi konstitusi atau tidak. Di satu sisi yang menyetujui dimasukkannya hak sosial ekonomi dalam konstitusi mengatakan bahwa hampir tidak ada artinya untuk mengatakan bahwa hak sipil dan politik akan terlindungi, jika mereka tunduk pada eksploitasi sosial. Jika hak ekonomi dan sosial tidak diberi perlindungan konstitusional yang berarti, konstitusi akan mengalami delegitimasi karena rakyat akan mengatakan bahwa konstitusi tersebut tidak berkaitan dengan kebutuhan fundamentalnya. Di lain pihak jika hak sosial dan ekonomi dimasukkan dalam konstitusi, akan mendelegitimasi konstitusi, karena ia terlalu banyak berjanji, dan akan kehilangan kredibilitas karena tidak bisa memenuhinya karena keterbatasan sumber daya. ${ }^{12}$ UUD 1945 sejak awal sudah memuat hakhak sosial dan ekonomi ini dalam UUD 1945. Bahkan dalam bab tentang Pendidikan dan Kebudayaan, pendidikan dasar telah menjadi hak konstitusional yang wajib dibiayai Pemerintah dengan alokasi anggaran sebagai prioritas minimal 20\% dari Anggaran Pendapatan Dan Belanja Negara. Konstitusi sebagai aturan dan hukum dasar yang seyogianya memuat prinsip-prinsip umum pemerintahan, secara menyimpang dari kebiasaan, mengatur satu angka secara konkrit meskipun tidak bersifat absolut melainkan relatif, yang membawa implikasi di bidang ekonomi dan keuangan, yang membutuhkan langkah positif untuk menegakkan hak sosial dan ekonomi tersebut. Tetapi negara bekas anggota Uni-Soviet yang beralih menjadi negara demokrasi, meskipun diberi nasehat untuk tidak memasukkan hak sosial ekonomi tersebut dalam konstitusi, hampir semuanya dimuat dalam konstitusi mereka, dan putusan MK mereka tidak dipersoalkan oleh Pemerintah dan dilaksanakan dengan sepatutnya. ${ }^{13}$

\footnotetext{
${ }^{11}$ Herman Schwartz, Do Economic and Social Rights Belong In A Constitution ?, 10 Am.U.J. Int'1 L \& Pol'y 1994-1995, hlm. 1235. Dia mengatakan:" To most American lawyers, putting economic and social rights in a constitution verges on the unthinkable. Americans are taught to think that constitutional rights depend on judicial enforceability almost by definition.

${ }^{12}$ Christof Heyns, Introduction To Socio-Economic Rights In The South African Constitution[Part 1], hal 2, tanpa tahun.

${ }^{13}$ Herman Schwartz, op.cit.
} 
Oleh karenanya menjadi penting untuk mengetahui bagaimanakah implementasi putusan MK tersebut dilakukan. Apakah penyelenggara kekuasaan negara dibidang legislatif dan eksekutif merasakan implementasi putusan MK sebagai kewajiban konstitusional mereka. Terlepas dari ketiadaan mekanisme yang jelas tentang bagaimana proses implementasi dilakukan serta tidak adanya instrumen pemaksa pada MK untuk memaksakan implementasi putusannya yang belum dilaksanakan, maka MK tentu saja berkepentingan untuk melihatnya dilaksanakan. Satu putusan yang tidak terlaksana sebagaimana layaknya dalam jangka waktu yang pantas, tentu saja akan membawa dampak pada kewibawaan lembaga yang memutusnya, serta penegakan hukum dan konstitusi pada umumnya. Secara logis, jika MK merupakan pengawal konstitusi sebagaimana selalu dinyatakan, maka tidak terlaksananya putusan MK sebagaimana mestinya sedikit banyak dapat menimbulkan terjadinya proses deligitimasi terhadap UUD 1945, yang pada hakekatnya dapat menggoyahkan stabilitas penyelenggaraan kehidupan berbangsa dan bernegara. Oleh karenanya menjadi sesuatu hal yang penting bahwa pada akhirnya putusan MK yang sangat mendasar akan terlaksana. Dengan perkataan lain dimanakah sesungguhnya letak kekuatan akhir yang dapat memaksakan implementasi atas putusan demikian yang sumbernya adalah UUD 1945 sebagai hukum dasar. Krisis ketatanegaraan merupakan satu kondisi yang diperhitungkan dapat terjadi jikalau dalam menyelenggarakan tugas konstitusionalnya Pemerintah dan DPR-- sebagai pemegang mandat rakyat-- menyusun kebijakan yang tidak sesuai dengan kehendak "majikan".

\section{Penegakan Hukum Konstitusi}

Putusan pengadilan biasa yang telah berkekuatan tetap yang bersifat inter-partes atau yang mengikat di antara pihak-pihak berperkara, putusan mana mengandung penghukuman atau perintah untuk melakukan satu perbuatan atau menyerahkan sesuatu barang sebagai prestasi salah satu pihak berperkara, memberi hak pada pihak yang dimenangkan oleh pengadilan untuk meminta pelaksanaan putusan tersebut (eksekusi) oleh pihak yang kalah, melalui kekuasaan pengadilan dan instrumen pemaksa yang berada dibawah kontrol pengadilan. Perlunya upaya paksa untuk mendukung eksekusi putusan pengadilan terjadi ketika pihak yang diwajibkan melakukan sesuatu atau menyerahkan sesuatu barang kepada 
pihak lawan, tidak dipatuhi secara sukarela dalam waktu yang ditentukan. Bahkan dalam keadaan dimana instrumen pemaksa (sterke arm) sudah digerakkan untuk melaksanakan putusan in-kracht demikian, sering juga pihak yang kalah berusaha dengan sekuat tenaga dan dengan segala cara, termasuk cara kekerasan, untuk menghindari atau menghalangi proses eksekusi yang tengah berjalan. Kecuali karena adanya alasan objektif yang menyangkut objek perkara yang akan dieksekusi maupun situasi para pihak berperkara telah menjadi sedemikian rupa perubahan keadaannya atau hubungan hukumnya sehingga tidak dapat dieksekusi (non-eksekutabel), maka putusan pengadilan biasa yang berisi perintah untuk melakukan sesuatu atau menyerahkan sesuatu yang lazim disebut sebagai eksekusi riel, dapat dipaksakan pelaksanaannya dengan alat kekuasaan negara. ${ }^{14}$

Akan tetapi tidak demikian halnya dengan putusan MK dalam pengujian undang-undang. Sebagai satu mekanisme checks and balances putusan MK yang mengabulkan satu permohonan untuk menyatakan satu undang-undang, pasal, ayat dan/atau bagian dari undang-undang bertentangan dan tidak mempunyai kekuatan hukum mengikat, terlebihlebih jika menyangkut pengujian undang-undang yang bersifat beleidsregels, yang tidak bersifat self-executing, ${ }^{15}$ tidak selalu mudah untuk diimplementasikan. MK sebagai negative legislator, yang telah membentuk hukum baru dengan menyatakan satu undang-undang, pasal, ayat dan/ atau bagian dari undang-undang tidak lagi mempunyai kekuatan hukum mengikat, tidak diperlengkapi dengan suatu instrumen yang dapat memaksakan bahwa putusan tersebut harus dilaksanakan, baik melalui kekuatannya sendiri maupun dengan cara-cara lain. Sebagai akibatnya,

${ }^{14}$ Eksekusi dalam perkara perdata diatur dalam Bagian 5 H.I.R (Reglemen Indonesia Yang Diperbaharui, pasal 195 dan seterusnya. Jika pihak yang dikalahkan tidak mau atau lalai memenuhi keputusan dengan baik, maka pihak yang dimenangkan mengajukan permintaan kepada Ketua Pengadilan Negeri, kemudian Ketua itu akan memanggil pihak yang kalah itu, serta menegurnya supaya ia memenuhi keputusan itu dalam waktu yang ditentukan. Jika lewat waktu yang ditentukan itu sedangkan orang yang kalah itu belum juga memenuhi keputusan, maka ketua karena jabatan nya akan memberi perintah dengan surat supaya disita barang bergerak, dan kalau tidak cukup barang tidak bergerak kepunyaan orang yang kalah itu.

${ }^{15}$ Self-executing disini diartikan bahwa putusan akan langsung effektif berlaku tanpa diperlukan tindak lanjut lebih jauh dalam bentuk kebutuhan implementasi perubahan undang-undang yang diuji. 
maka dalam dinamika kepentingan politik diantara kekuatan dalam masyarakat yang dapat mendorong atau menghambat implementasi putusan MK, yang tidak selalu dapat diterima semua pihak, akan memperhadapkan MK dengan kekuasaan negara lainnya, yaitu legislatif bersama-sama dengan eksekutif, sebagai badan pembuat undang-undang, yang juga tidak selalu berkepentingan untuk melaksanakannya. Setidaktidaknya jika putusan tersebut merugikan kepentingan mereka masingmasing. Oleh karenanya kecenderungan untuk mengabaikan, melawan atau menentang putusan MK juga terjadi dalam peradilan konstitusi, terutama jikalau putusan MK tersebut terlalu merugikan kepentingan politik pihak eksekutif maupun legislatif yang terdiri dari kekuatankekuatan partai politik yang mempunyai kursi di DPR. Perlawanan atau tantangan tersebut akan bisa mengambil bentuk dengan mengabaikan putusan, menolak revisi undang-undang yang telah diuji atau bahkan melakukan serangan balik baik dengan upaya mengurangi kewenangan MK atau mendudukkan orang-orang yang lebih lembek untuk mengisi posisi hakim MK yang lowong pada masa jabatan berikut. ${ }^{16}$ Dalam peran MK yang demikian kuat dan mendasar sebagai penyeimbang dan pengawasan horizontal, menjadi sangat wajar jikalau hubungan antara MK dan Eksekutif dan legislatif boleh jadi akan berada dalam ketegangan atau suasana yang dingin. Undang-undang sebagai produk proses politik yang diuji oleh MK sebagai kewenangan yang diterapkan untuk mencegah proses kebijakan yang bisa menyimpang jauh dari mandat konstitusi, sehingga lembaga yang tidak demokratis seperti MK sesungguhnya membantu dan mendukung democratic majoritarianism dengan bersikeras mendesak agar lembaga-lembaga politik bertindak dalam kerangka kekuasaan yang disebut dalam konstitusi, agar ketika merumuskan undang-undang memperhitungkan batas-batas konstitusional yang ada. ${ }^{17}$ Dalam ketegangan hubungan yang bisa terjadi antara MK dengan Pembuat Undang-Undang, harus selalu dicoba adanya dialog secara terus menerus diantara ketiganya, yang meungkinkan timbulnya saling pemahaman, yang pada gilirannya dapat mempermudah proses implementasi putusan yang kontroversial sekalipun, sehingga semua pihak dapat mengidentifikasi batas-batas kewenangan konstitusional masing-

${ }^{16}$ Tom Ginsburg,Judicial Review In New Democracies, Constitutional Court in Asian Cases, Cambridge University Press 2003, hlm. 78-79.

${ }^{17}$ Howard Ball, op.cit., hlm. 19. 
masing secara wajar dan masuk akal,tanpa menimbulkan ketegangan dan kebuntuan politik yang tidak perlu. Tambahan lagi hampir semua negara dimana Mahkamah Konstitusi dibentuk terpisah dari Mahkamah Agung, timbul persaingan atau perasaan disaingi dilingkungan Mahkamah Agung, didalam urusan teknis perkara ataupun nonperkara. ${ }^{18}$

Dalam kenyataan, ternyata masih banyak putusan MK yang belum ditindak lanjuti sebagai implementasi dalam bentuk revisi undang-undang yang telah diuji MK; dalam beberapa putusan lainnya, proses implementasinya berjalan sangat lamban dan penuh dengan tarik menarik kepentingan yang memang dapat diperhitungkan dari sejak awal. Ada pula yang berpendapat bahwa putusan MK dalam banyak hal tidak menyelesaikan masalah, ${ }^{19}$ melainkan justru menimbulkan masalah baru, karena dalam mewujudkan perubahan hukum yang ditetapkan secara declaratoir dalam putusannya, justru membutuhkan kembali perdebatan dan proses seperti dalam pembentukan satu undang-undang baru. Hal demikian ada benarnya, karena putusan MK yang menyangkut pengujian undang-undang yang bersifat algemene verbindende voorschriften (aturan yang mengikat secara umum) tentang larangan dan keharusan yang dinyatakan bertentangan dengan UUD 1945 dan tidak lagi mempunyai kekuatan hukum mengikat, telah dengan sendirinya berlaku dan mengikat dengan dibacakannya di depan sidang terbuka untuk umum putusan yang bersifat deklaratif konstitutif tersebut. Pejabat negara terutama penegak hukum, terikat untuk tidak menerapkan lagi aturan undang-undang yang telah dinyatakan inkonstitusional dan tidak mempunyai kekuatan hukum mengikat tersebut. ${ }^{20}$ Permasalahannya adalah, apakah dengan dipublikasikannya putusan MK dalam Berita Negara, menyebabkan undang-undang yang telah diuji sepanjang mengenai pasal, ayat atau

${ }^{18}$ Jimly Asshidiqie, Pokok-Pokok Hukum Tata Negara Indonesia Pasca Reformasi, PT Bhuana Ilmu Populer, Kelompok gramedia, 2007, hlm. 608.

${ }^{19}$ Putusan hakim MK yang dapat didefinisikan sebagai pendapat MK secara tertulis tentang apa yang menjadi norma konstitusi yang ditafsirkan dari teks UUD 1945 tertentu, untuk diterapkan dalam penyelesaian perselisihan yang dihadapkan padanya.

${ }^{20}$ Ditemukannnya fakta bahwa ada Hakim, Jaksa dan Polisi yang masih menggunakan norma undang-undang yang telah dinyatakan tidak mempunyai kekuatan hukum mengikat sebagai dasar hukum bagi putusan, tuntutan dan penyidikan, tidak mengurangi kekuatan hukum mengikat putusan tersebut. Proses atau mekanisme yang dapat digunakan oleh pihak yang dirugikan oleh sikap pejabat demikian tersedia dalam bentuk gugat atas perbuatan melawan hukum. 
bagian undang-undang yang dinyatakan tidak mempunyai kekuatan hukum mengikat tersebut dapat dihapuskan dengan sendirinya dari undang-undang yang bersangkutan, sebagaimana dilakukan oleh penyusun himpunan perundang-undangan tertentu. ${ }^{21}$ Apakah putusan MK sebagai negative legislator yang berada dalam posisi sejajar dengan pembuat undang-undang positif, yaitu Presiden dan DPR, dalam hal perubahan yang terjadi sangat minor atau hanya menyangkut satu dua pasal atau ayat, tidak sebaiknya harus dilakukan dengan mencatatkan bunyi putusan MK tersebut sebagai catatan pinggir atau renvoi dalam Lembaran Negara tempat diundangkannya undang-undang yang diuji tersebut.

Adanya perbedaan jenis undang-undang yang telah disinggung terdahulu, menunjukkan bahwa ada undang-undang yang hanya dalam arti formil (wet in formele zijn), ${ }^{22}$ yang sesungguhnya tidak berlaku dan mengikat secara umum, melainkan memuat rencana, pengaturan dan kebijakan makro dalam perekonomian seperti halnya undang-undang APBN. Peraturan yang dinamakan policy rules atau beleidsregels, ${ }^{23}$ jika

${ }^{21}$ Misalnya Himpunan Peraturan Perundang-undangan R.I., PT Ichtiar Baru Van Hoeve, menuliskan Pasal 16 dan 17 UU nomor 20 tahun 2001 tentang Minyak dan Gas Bumi, dibuatkan catatan bahwa pasal tersebut dibatalkan oleh Mahkamah Konstitusi dengan Putusan Mahkamah tahun 2006, tetapi tidak memuat seluruh putusan MK yang menyatakan pasal, ayat dan/atau bagian undang-undang yang telah dinyatakan tidak mempunyai kekuatan hukum mengikat.

${ }^{22}$ Perbedaan undang-undang dalam arti formil (wet in formele zin) dan undangundang dalam arti materil (wet in materiele zin) didasarkan bukan hanya pada siapa pembuatnya, melainkan dapat juga dari substansi yang dikandung. Undang-Undang dalam arti formil (wet in formele zin) oleh sebagian penulis dipandang sesungguhnya lebih tepat disebut formele wetten atau formell gezetz, yang di Belanda dibuat Regering bersama Staten General(Maria Farida Indrati Suprapto, Ilmu Perundang-undangan, Penerbit Kanisius 1998, hal 33). Bandingkan juga dengan H.A.S. Natabaya, Sistem Peraturan Perundang-Undangan Indonesia, Sekkretariat Jenderal dan Kepaniteraan Mahkamah Konstitusi R.I. 2006, hal 11-14). Dalam Pasal 20 ayat (1) dan (2) UUD 1945 setelah Perubahan Pertama dikatakan bahwa DPR memegang kekuasaan membuat undang-undang, yang setiap rancangannya dibahas bersama Presiden untuk mendapat persetujuan bersama, sedang Pasal 5 ayat (1) UUD 1945 sebelum perubahan menyatakan Presiden memegang kekuasaan membentuk undangundang dengan persetujuan DPR.

${ }^{23}$ Jimly Asshidiqie, Perihal Undang-Undang, Konpress 2006 hlm. 20. Dikatakan bahwa hal itu akan berbeda dengan peraturan perundang-undangan yang bersifat umum, yaitu berlaku umum bagi siapa saja dan bersifat abstrak karena tidak menunjuk kepada hal atau peristiwa atau kasus konkrit yang sudah ada sebelum peraturan ditetapkan; suatu norma hukum dikatakan bersifat abstrak jika 
implementasi putusan MK memerlukan satu rencana atau kebijakan baru melalui revisi undang-undang berdasarkan tafsir dan operative proposisition $^{24}$ yang dikeluarkan $\mathrm{MK}$, yang akan dijadikan dasar hukum dalam menyelenggarakan kegiatan negara selanjutnya, maka keadaanya menjadi berbeda. Kita memahami bahwa hukum memiliki tiga aspek atau komponen, yaitu (i) nilai, (ii) norma, dan (iii) realitas sosial. Hukum sebagai ideal yang memuat nilai-nilai berkait erat dengan konseptualisasi keadilan secara abstrak. Tetapi hukum merupakan lembaga peraturan yang harus memperhatikan kenyataan sehari-hari, dan ia harus mencerminkan kenyataan sehari-hari yang hidup, serta menjejakkan kaki kebumi, sehingga merupakan hal yang wajar jika timbul tegangan antara dunia idee atau nilai dengan dunia sehari-hari tersebut. Ide atau nilai itu berubah fungsinya menjadi kekuatan pengontrol. ${ }^{25}$

Putusan MK dalam pengujian undang-undang formil yang tidak bersifat algemene verbindende regels sebagaimana telah diutarakan di atas barulah menyelesaikan tahap penyelarasan prescription of norms kepada nilai-nilai yang termuat dalam UUD 1945, yang menegasikan norma undang-undang yang diuji kepada nilai yang terkandung dalam hukum dasar atau hukum tertinggi, yang tidak mungkin serta merta diperlakukan tanpa menuangkan kebijakan dan rencana perhitungan baru sebagai perubahan yang diperintahkan dalam revisi undang-undang yang telah diuji dengan putusan MK. Dengan kata lain dibutuhkan implementasi yang akan dilaksanakan oleh addresat putusan MK yakni DPR dan Pemerintah. Perubahan tersebut menyangkut tertib hukum ataupun kebijakan yang baru, karena MK baru sampai pada tahap mendefinisikan kembali bagaimana norma dan standar dalam kebijakan yang dimuat dalam undang-undang a quo harus dirumuskan. Dengan petunjuk konstitusional demikian pembuat undang-undang harus merumuskan kembali preskripsi norma yang serasi dengan nilai dalam hukum tertinggi yaitu UUD 1945. Proses pembuatan atau revisi undang-undang demikian harus kembali menempuh tingkat-tingkat yang dikenal dalam

rumusannya berisi nilai baik buruk sehingga harus dilarang (prohibere), disuruh (obligatere), ataupun diperbolehkan (permittere), yang tidak secara langsung dikaitkan dengan subjek-subjek, keadaan atau peristiwa konkrit tertentu. (hlm 19)

${ }^{24}$ Istilah tersebut digunakan oleh Mitchell N. Berman, dalam artikel Constitutional Decision Rules, Virginia Law Review, Vol 90, no. 1 March 2004, yang merupakan pedoman yang diperoleh sebagai hasil interpretasi Konstitusi.

${ }^{25}$ Satjipto Rahardjo, Ilmu Hukum, Penerbit PT. Citra Aditya Bakti, Bandung 2000, hlm. 169-170. 
proses pembentukan undang-undang tentang tatacara pembuatan peraturan perundang-undangan yang berlaku sekarang. ${ }^{26}$

\section{Beberapa Masalah yang Dihadapi}

Dengan uraian sebagaimana dikemukakan terdahulu, penegakan hukum (konstitusi) terjadi melalui serangkaian proses panjang dengan berbagai variabel turut mempengaruhi hasil yang dicapai. Oleh karenanya sangat penting untuk diketahui bagaimana addressat putusan MK seharusnya memahami dan menghayati makna "putusan MK sebagai putusan tingkat pertama dan terakhir yang bersifat final", sebagaimana dirumuskan dalam pasal 24C ayat (1) UUD 1945, yang kemudian diulangi dalam pasal 10 ayat (1) Undang-Undang nomor 24 tahun 2003 tentang Mahkamah Konstitusi. Satu putusan yang final dan memperoleh kekuatan hukum tetap sejak diucapkan dalam sidang pleno terbuka untuk umum, ${ }^{27}$ membawa akibat materi muatan ayat, pasal, dan/atau bagian undangundang ataupun undang-undang secara keseluruhan tidak lagi mempunyai kekuatan hukum mengikat. ${ }^{28}$ Hal demikian memiliki implikasi atau akibat hukum yang sama dengan diundangkannya satu undangundang yaitu bersifat erga omnes, ${ }^{29}$ yaitu mengikat seluruh warganegara, pejabat negara dan lembaga-lembaga negara sesuai dengan sifat negara hukum.

${ }^{26}$ Undang-Undang Nomor 10 tahun 2004 Tentang Pembentukan Peraturan Perundang-undangan. Rancangan Undang-Undang disusun berdasarkan Program Legislasi Nasional, akan tetapi dalam keadaan tertentu dapat diajukan rancangan undang-undang diluar Program Legislasi Nasional.(Pasal 17 Ayat (1) dan (3) UU nomor 10 tahun 2004. Putusan MK yang mengharuskan satu revisi atas undangundang yang telah diuji, hemat saya merupakan alasan bahwa meskipun tidak tercantum dalam program legislasi nasional, rancangan demikian dapat menjadi materi pembahasan di DPR.

${ }^{27}$ Pasal 47 Undang-Undang nomor 24 tahun 2003.

${ }^{28}$ Pasal 57 ayat (1) dan ayat (2) Undang-Undang Nomor 24 tahun 2003.

${ }^{29}$ Erga Omnes (Latin : in relation to everyone) istilah yang sering dipergunakan dalam bidang hukum untuk menjelaskan hak-hak atau kewajiban yang berlaku terhadap semua pihak. Misalnya satu hak milik merupakan hak yang bersifat erga omnes, dan oleh karenanya dapat dapat dilaksanakan dan ditegakkan terhadap setiap orang jikalau terjadi pelanggaran terhadap hak tersebut. Suatu hak yang bersifat erga omnes yang didasarkan pada undang-undang dapat dibedakan dari satu hak yang timbul atas dasar perjanjian atau kontrak, yang hanya dapat dilaksanakan terhadap para pihak dalam perjanjian tersebut (inter partes). 
Apabila Pemerintah dan DPR memahami keterikatan tersebut dalam arti menjadi kewajiban konstitusionalnya untuk melaksanakan putusan MK sebagai negative legislator, seharusnya ada prosedur baku yang ditetapkan tentang mekanisme untuk implementasi putusan tersebut, sehingga tidak semata-mata tergantung pada nilai, etika dan moralitas yang dianut oleh anggota-anggota DPR dan Pejabat Pemerintah yang berwenang. Prosedur baku yang mengikat tersebut diperlukan karena terdapat akibat hukum yang berbeda-beda sesuai dengan jenis undangundang yang diuji dan dinyatakan inkonstitusional sehingga tidak mempunyai kekuatan hukum mengikat. Dengan demikian sebagai konsekuensinya, maka implementasi putusan MK yang menguji undangundang, proses dan mekanismenya tidak sama karena Undang-Undang terdiri dari beberapa macam atau jenis dilihat dari substansi norma, subjek yang sesungguhnya maupun daya ikat. Dikenal adanya undang-undang formil yang dibedakan dari undang-undang dalam arti materil. Undangundang formil yang hanya dapat dibentuk Pemerintah dan DPR, dalam kenyataanya tidak selalu bermuatan norma perilaku tentang larangan dan kewajiban, yang sifatnya berupa algemene verbindende voorschriften, tetapi dapat juga berupa kebijakan (beleidregels), pengaturan ataupun rencana perhitungan pendapatan dan pengeluaran negara yang sematasemata berupa perkiraan. Perbedaan isi atau materi undang-undang tersebut sedemikian rupa membawa akibat dalam putusan pengujian, yang meskipun sama-sama tidak mempunyai kekuatan hukum mengikat, namun bentuk pelaksanaan atau implementasi pernyataan tidak mempunyai kekuatan hukum mengikat terhadap undang-undang demikian yang bersifat inkracht van gewijsde tetap saja tidak sama. Hal demikian antara lain juga karena dalam kenyataan MK tidak memiliki instrumen untuk memaksakan pelaksanaan atau implementasi putusannya. Oleh karena itu menjadi penting untuk diketahui dimanakah letak kekuatan terakhir untuk memaksakan implementasi putusan yang final dan mengikat tersebut secara konstitusional dalam sistim ketatanegaraan kita. Dengan demikian secara umum masalah yang dihadapi adalah apa dan bagaimana tindak lanjut atas putusan MK yang dilakukan oleh badan legislatif dan eksekutif sebagai bagian proses penegakan hukum, dengan mana dapat diketahui bagaimana sesungguhnya meletakkan peran putusan Mahkamah Konstitusi dalam pengujian undang-undang, untuk mewujudkan satu penegakan checks and balances yang efektif dalam penyelenggaraan kekuasaan negara yang 
demokratis berdasarkan prinsip konstitusionalisme, sehingga dapatlah dirancang tehnik dan strategi untuk memberdayakan mekanisme sistem ketatanegaraan kita berkenaan dengan implementasi putusan MK secara efektif sebagai bagian dari proses penegakan hukum. Apabila ternyata hal itu tidak efektif, dapat diketahui titik-titik lemah untuk melakukan perbaikan dan perubahan UU Mahkamah Konstitusi maupun mekanisme implementasi putusan MK sebagai negative legislation agar efektif menjadi positive legislation melalui implementasi atau tindak lanjut yang dilakukan DPR dan Pemerintah terhadap putusan MK tersebut. Hal ini menjadi penting, karena hukum tatanegara, yang baru saja bangun dari tidurnya, memerlukan pengujian yang kritis untuk dapat menjadi hukum yang hidup melalui praktek dan putusan Mahkamah Konstitusi. Georg Vanberg dalam bukunya The Politics of Constitutional Review in Germany, menguraikan hubungan legislatif-judikatif berkenaan dengan wewenang constitutional review yang dimiliki oleh Federal Constitutional Court Jerman. Buku lain adalah Ralf Ragowski dan Thomas Gawron, ${ }^{30}$ yang menghimpun tulisan tentang implementasi putusan Mahkamah Agung Amerika dan Jerman dalam satu perspektif perbandingan. Sistem hukum dan kewenangan Mahkamah Agung Amerika Serikat yang didasarkan pada common law, berbeda dengan sistem hukum Indonesia dengan Mahkamah Konstitusi, menyebabkan problematik dan mekanisme implementasi putusan Mahkamah Agung Amerika Serikat berbeda pula. Demikian pula sistem hukum ketatanegaraan dan politik di Jerman yang memiliki Mahkamah Konstitusi dengan keberadaan yang lebih mapan, berbeda pula dengan sistim yang berlaku di Indonesia, yang menyebabkan mekanisme implementasi putusan MK telah diterima secara lebih integratif dalam kehidupan hukum dan politik secara stabil dan predictable.

\section{Popular Support sebagai Kekuatan Pemaksa Implementasi}

Putusan MK dalam pengujian UU terhadap UUD 1945 adalah wujud dan bentuk judicial control dalam mekanisme cheks and balances di antara cabang kekuasaan negara khususnya checks and balances dari kekuasaan kehakiman terhadap kekuasaan legislatif atau pembuatan undangundang. Mekanisme pengawasan yang dilakukan didasarkan pada

\footnotetext{
${ }^{30}$ Constitutional Courts in Comparison, The US Supreme Court and the German Federal Contituional Court,Ralf Rogowski \& Thomas Gawron (eds), Berghahn Books, New York-Oxford, 2002.
} 
penyelarasan terhadap konstitusi sebagai hukum dasar dan hukum tertinggi yang menjadi sumber legitimasi aturan perundang-undangan yang berada di bawahnya, baik atas perintah UUD 1945 maupun sebagai penjabaran dan pelaksanaannya. Supremasi Konstitusi yang ditegakkan oleh MK melalui kewenangan uji materil terhadap UU yang dihasilkan legislatif adalah untuk menjamin bahwa UU yang dihasilkan tersebut sesuai dengan UUD. Secara tegas UUD 1945 memberi kewenangan tersebut kepada MK dalam kerangka pembagian kekuasaan (separation of powers) dan karenanya jikalau MK sewaktu-waktu menyatakan satu UU yang dihasilkan pembuat UU dinyatakan tidak lagi mempunyai kekuatan hukum mengikat atau batal hal itu dilakukan bukan sebagai indikasi superioritas MK terhadap cabang kekuasaan legislatif melainkan hanya melaksanakan kewajiban suci dan khidmat yang dilimpahkan oleh Konstitusi padanya. Sesungguhnya yang mengawasi dan mengukur tiap produk legislatif adalah UUD itu sendiri dengan menolak meluluskan tiap UU yang tidak sesuai dengan UUD itu sendiri. Tetapi setiap kewenangan yang dimiliki oleh jabatan ( $a m b t$ ) hanya bisa digerakkan melalui pejabatnya (ambtdrager) sendiri yang akan mengaplikasikan kewenangan yang statis tersebut dalam satu dinamika kehidupan dan penyelenggaraan negara.

Akan tetapi ketika satu putusan telah diambil dan MK menyatakan materi ayat, pasal, dan/atau bagian dari UU atau UU-nya secara keseluruhan dinyatakan tidak mempunyai kekuatan hukum dan tidak berlaku, apakah dengan sendirinya putusan tersebut akan terlaksana atau harus ada satu proses yang mengikutinya. Sudah jelas, satu perubahan keadaan hukum melalui putusan yang bersifat declaratoir dan constitutief demikian yang mempengaruhi secara signifikan satu UU yang berlaku, baik karena adanya kekosongan hukum (rechtsvacuum) maupun karena berubahnya pengertian atau makna satu norma berdasar tafsiran yang dihasilkan hakim MK, membutuhkan tindak lanjut atau mekanisme pelaksanaan. MK tidak memiliki aparat dan kelengkapan apapun untuk menjamin penegakan keputusannya meskipun secara alamiah kelembagaan, MK berkepentingan untuk melihat putusannya dihormati dan dipatuhi. Tidak ada polisi atau juru sita pengadilan atau instrumen lain untuk melaksanakan apapun yang diputuskan MK atau yang menurut putusan tersebut harus dilaksanakan. Oleh sebab itulah kekuasaan kehakiman khususnya MK dapat dipandang sebagai cabang kekuasaan negara yang paling lemah (the least dangerous power, with no purse nor 
sword). ${ }^{31}$ MK bergantung pada cabang kekuasaan lain atau organ-organ lain, apakah putusan-putusannya diterima dan apakah mereka siap untuk mematuhinya. Alat kekuasaan MK yang sebenarnya sebagai instrumen pelaksanaan keputusan-keputusannya adalah konstitusi itu sendiri. ${ }^{32}$

Addresat putusan MK untuk melaksanakan putusan tersebut meliputi DPR dan Pemerintah yang masing-masing berwenang untuk mengajukan rancangan revisi UU yang dibatalkan tersebut. Tetapi Pemerintah juga dengan kewenangan untuk mengeluarkan Peraturan Pemerintah untuk melaksanakan satu UU sebagaimana telah berubah oleh putusan MK maupun Pemerintah Daerah dalam pembuatan Peraturan Daerah sebagai pelaksanaan UU juga mempunyai kewajiban konstitusional demikian. DPR adalah sebagai organ yang mempunyai fungsi legislasi dengan persetujuan Pemerintah. ${ }^{33}$ Hakim Pengadilan juga melaksanakan putusan MK ketika UU yang telah dinyatakan tidak lagi mempunyai kekuatan hukum mengikat, dan dengan keadaan hukum yang baru tersebut hakim terikat untuk menerapkannya pada kasus yang dihadapinya untuk diputus. Tetapi khusus untuk keadaan di Jerman, departemen tertentu negara federal khususnya departemen kehakiman bertindak sebagai agen pelaksana yang memonitor respon legislatif terhadap putusan MK. Setelah tahun 1979, terdapat satu bagian khusus di departemen kehakiman yang bertanggung jawab atas hukum konstitusi (tatanegara) yang segera bertugas menghimpun daftar perintah putusan MK dan segera mengirimkan daftar itu ke Kementerian dan dibagikan kepada Kementerian yang bertanggung jawab untuk membuat rancangan ulang setiap enam bulan. ${ }^{34}$ Pasal 136 ayat (2) Konstitusi Italia menentukan bahwa dalam hal MK Italia menentukan satu UU inkonstitusional, putusan demikian dikirimkan ke DPR dan Dewan Daerah (Regional Councils) agar supaya dapat diambil langkah-langkah dalam bentuk konstitusional jika dipandang perlu. Ketentuan ini dimaksudkan agar putusan yang MK kirimkan tersebut dalam hal dipandang perlu didorong untuk mengambil langkah revisi undang-undang yang dibatalkan MK tersebut. Ketentuan untuk mengirimkan putusan MK kepada DPR, DPD, Presiden, dan

${ }^{31}$ Alexander Hamilton, The Federalist Papers, Mentor Book, The New American Library, 1961

${ }^{32}$ Ernst Benda, Pelaksanaan Keputusan Mahkamah Konstitusi di Negara-Negara Transformasi dengan Contoh Indonesia, Konrad Adenauer Stiftung, Jakarta, 2005, hlm 15.

${ }_{33}$ Pasal 5 dan Pasal 20A Undang Undang Dasar 1945.

${ }^{34}$ Ralf Ragowski\& Thomas Gawron, Op.Cit., hlm. 247. 
Mahkamah Agung ditemukan juga dalam pasal 59 UU nomor 24 tahun 2003, akan tetapi aturan tersebut tidak secara eksplisit menyebut bahwa dikirimkan salinan putusan MK tersebut adalah dalam rangka mengambil langkah-langkah yang perlu menindak lanjuti putusan dalam bentuk perubahan atau revisi undang-undang yang diuji bila dipandang perlu.

Addresat putusan MK yang tidak senang atau tidak setuju mempunyai 4 (empat) pilihan menghadapi putusan MK tersebut. Pertama, ia dapat patuh terhadap putusan tersebut dan menerimanya secara sukarela serta melaksanakannya. Atau kedua, dia dapat mengabaikan putusan MK dan berharap bahwa apapun wewenang yang dimiliki MK dan lembaga lain untuk melaksanakan, putusan itu menjadi tidak efektif. Ketiga, dia dapat mencoba membatalkan putusan melalui amandemen UUD atau jika ada prosedur yang tersedia secara resmi menolak putusan. Opsi terakhir dan yang paling ekstrim atau yang keempat adalah dengan menyerang MK sebagai lembaga dengan berupaya mengurangi wewenangnya atau kekuasaan efektifnya. ${ }^{35}$

Secara berbeda seorang penulis mengemukakan satu mekanisme yang memberi kekuatan pada putusan MK dari segi masalah implementasi yakni dukungan masyarakat (public support) bagi satu peradilan yang bebas. Dari pendekatan yang diajukan Tom Ginsburg di atas dapat diketahui bahwa addresat putusan MK ada kemungkinan mengelak atau mengabaikan putusan MK. Tetapi politisi di negara demokrasi yang membutuhkan dukungan masyarakat agar tetap berada dalam tampuk kekuasaan secara efektif memiliki perhitungan politik tersendiri. Hubungan sederhana antara dukungan masyarakat (public) dengan kekuasaan politik menyediakan satu mekanisme yang kuat bagi pelaksanaan putusan MK. Jika warga menghargai kemandirian MK dan memandang penghormatan atas putusan MK penting maka sikap pejabat untuk menolak putusan MK boleh jadi mengakibatkan hilangnya dukungan publik yaitu warga mencabut dukungannya pada pemilihan umum. Kekhawatiran akan reaksi publik dapat menjadi satu dorongan yang kuat untuk melaksanakan putusan MK dengan tepat. ${ }^{36}$ Akan tetapi dukungan publik hanya

${ }^{35}$ Tom Ginsburg, Judicial Review in New Democracies, Constitutional Court in Asian Cases, Cambridge University Press 2003, hlm. 78-79.

${ }^{36}$ Georg Vanberg, The Politics of Constitutional Review In Germany, Cambridge University Press 2005, hlm. 20. Teori atau pengamatan Georg Vanberg untuk keadaan di Jerman, meskipun dengan sistim Parlementer,dimana kekuasaan membuat 
dimungkinkan jika warga negara menjadi sadar dan yakin bahwa legislatif telah mencoba mengelakkan putusan MK, melalui adanya tranparansi kebijakan publik. Transparansi ini dipengaruhi banyak faktor, khususnya yang paling utama adalah pengaruh pemimpin opini dan liputan media adanya kepentingan yang terorganisasi yang mendapat insentif untuk meminta perhatian akan adanya upaya pengelakan putusan serta kompleksitas masalah yang dihadapi. ${ }^{37}$

Teori ini dapat diterapkan di Indonesia sebagai negara demokrasi yang melaksanakan siklus pemilihan secara teratur untuk memilih langsung anggota legislatif, Presiden/Wakil Presiden dan para Gubernur, Bupati atau Walikota. Akan tetapi terlepas dari faktor dukungan publik yang dapat berperan menjadi mekanisme efektif untuk melaksanakan putusan MK yang harus diperhitungkan legislatif maupun eksekutif jika masih ingin bertahan dalam posisi kekuasaan, lebih jauh Vanberg mengatakan bahwa hal demikian lebih mungkin jikalau pejabat yang mencoba mengelak atau mengabaikan putusan tersebut ada kemungkinan terungkap kepada publik. Mengetahui hal ini biasanya sulit karena mereka yang mencoba menantang putusan MK itu melakukannya tidak secara terang-terangan kecuali mereka tahu bahwa MK dengan putusan itu tidak mendapat dukungan masyarakat.

Di samping masalah dukungan publik dan ancaman akan balasan publik melalui pemilu atas ketidak patuhan pembuat UU terhadap putusan MK sebagai salah satu aspek perhitungan yang dihadapi, Vanberg mengemukakan juga satu prediksi tentang pengaruh faktor kedua terhadap kepatuhan yaitu seberapa besar ongkos yang timbul bagi kepatuhan tersebut (cost of compliance). Jika biaya mematuhi putusan

Undang-Undang berada ditangan Bundesrat (DPR), akan tetapi sangat relevan untuk Indonesia. Lebih lanjut dia mengatakan bahwa untuk bertugas sebagai satu mekanisme pelaksanaan yang effektif, dukungan publik saja tidak cukup. Diperlukan dua keadaan utama untuk menyadap dimensi yang terpisah masalah pelaksanaan putusan:

Condition 1 : There must exist sufficient support for the court (or for a specific decision) to make an attempt at evasion unattractive.

Condition 2 : It must be sufficiently likely that citizens will become aware of an evasion attempt so that any support the court enjoys can be brought to bear against legislative majorities that choose not to comply with a decision.

Kalau salah satu kondisi itu tidak ada, dukungan publik tidak dapat bertindak sebagai satu mekanisme pelaksanaan yang effektif (hal 21.)

${ }^{37}$ Ibid., hlm. 45. 
MK meningkat akan semakin meningkat keinginan legislatif untuk melawan putusan dan berupaya untuk menghindar dari melaksanakan putusan. ${ }^{38}$

Dari hasil penelitian yang dilakukan, tampak bahwa pada umumnya putusan MK dihormati dan dipatuhi. Meskipun ada pendapat yang berbeda tentang perlu tidaknya revisi UU yang telah diuji dan materi muatan, ayat, pasal dan/atau bagian UU tertentu telah dibatalkan, ada pendapat yang mengatakan bahwa pengumuman putusan MK dalam Berita Negara telah cukup dan putusan itu berlaku sebagai perubahan hukum atas UU yang diuji. Akan tetapi dalam praktek, terutama putusan yang membatalkan UU yang diuji secara keseluruhan, revisi sebagai tindak lanjut dilaksanakan oleh pembuat UU sebagaimana mestinya. Sesuai dengan hipotesa yang diajukan oleh Georg Vanberg, apakah terbukti bahwa:

a. putusan MK yang membutuhkan biaya yang besar (costly), dan

b. putusan dengan tingkat kompleksitas yang tinggi.

akan mengalami kendala objektif untuk dipatuhi dan dilaksanakan. Dorongan untuk melaksanakan putusan yang menimbulkan biaya yang tinggi dan kompleksitas masalah sosial politik yang tinggi belum dapat diuji terhadap ketergantungan pada dukungan publik melalui pemilihan umum karena mekanisme cheks and balances melalui constitutional review belum dapat dilakukan karena usia MK belum melewati masa siklus pemilu.

\section{Penutup}

Penegakan hukum konstitusi yang tercermin dalam kewenangan Mahkamah Konstitusi sebagai bagian dari sistem pemisahan kekuasaan (separation of powers) dan checks and balances hanya efektif jikalau putusan MK diterima dan dilaksanakan oleh penyelenggara cabang kekuasaan negara lainnya, terutama Pembentuk Undang-Undang. Beberapa strategi dan teknik yang diterapkan oleh MK untuk mengawal putusanputusannya dalam bentuk antara lain Conditional Constitutionality dan Grace Period atau pemberian tenggang waktu pada Pembentuk UndangUndang untuk mengimplementasikan putusan MK yang menyatakan satu Undang-Undang Inkonstitusional, akan tetapi tidak segera atau serta

\footnotetext{
${ }^{38}$ Ibid., hlm. 130.
} 
merta menyatakannya tidak lagi mempunyai kekuatan hukum mengikat, tidak juga menjamin tegaknya hukum konstitusi melalui implementasi putusan MK tersebut. Dalam keadaan yang demikian, pada akhirnya diserahkan pada kedaulatan rakyat dalam siklus lima tahunan Pemilihan Umum, untuk menentukan apakah pemerintahan dan legislator yang menghindari atau mengelakkan implementasi putusan MK yang menjalankan amanat UUD 1945, masih akan diberi mandat untuk mewakili rakyat pemilih mewujudkan kepentingan dan kesejahteraannya atau tidak. Jikalau rakyat pemilih berpendapat bahwa pemerintahan dan legislator telah menjalankan kewenangan dan kekuasaannya tidak sesuai dengan mandat yang diberikan, maka mandat demikian akan dicabut dan akan diserahkan pada pemimpin baru, yang dipercaya akan dapat menjalankan mandat sesuai dengan perintah konstitusi. Dukungan dan kekuasaan yang memiliki daya paksa seperti ini, membutuhkan satu kondisi yang tercerahkan. Komunikasi yang dibangun MK dengan keterbukaan dan publikasi putusan-putusan serta seluruh kegiatannya, merupakan upaya untuk mencapai tujuan pencerahan pemegang kedaulatan rakyat untuk menjalankan kekuasaannya secara layak dalam proses demokrasi.

\section{Daftra Pustaka}

Alexander Hamilton, The Federalist Papers, Mentor Book, The New American Library, 1961.

Christof Heyns, Introduction To Socio-Economic Rights In The South African Constitution[Part 1], tanpa tahun.

Ernst Benda, Pelaksanaan Keputusan Mahkamah Konstitusi di Negara-Negara Transformasi dengan Contoh Indonesia, Konrad Adenauer Stiftung, Jakarta, 2005.

Georg Vanberg, The Politics of Constitutional Review In Germany, Cambridge University Press 2005.

Hans Kelsen, General Theory of Law And State, New York, Russel\&Russel, 1973.

H.A.S. Natabaya, Sistem Peraturan Perundang-Undangan Indonesia, Sekkretariat Jenderal dan Kepaniteraan Mahkamah Konstitusi R.I. 2006.

Herman Schwartz, Do Economic and Social Rights Belong In A Constitution?, 10 Am.U.J. Int'1 L \& Pol'y 1994-1995.

Howard Ball, Courts And Politics, The Federal Judicial System, Prentice-Hall Inc,Englewood Cliffs, N.J. 1980. 
Jimly Asshidiqie, Pokok-Pokok Hukum Tata Negara Indonesia Pasca Reformasi, PT Bhuana Ilmu Populer, Kelompok Gramedia, 2007. , Perihal Undang-Undang, Konpress 2006.

Jutta Limbach, The Concept of the Supremacy of the Constitution, dalam The Modern Law Review Vol.64, No. 1, Januari 2001.

Maria Farida Indrati Suprapto, Ilmu Perundang-undangan, Penerbit Kanisius 1998.

Mitchell N. Berman, dalam artikel Constitutional Decision Rules, Virginia Law Review, Vol 90, No. 1 March 2004

Ralf Rogowski \& Thomas Gawron (eds), Constitutional Courts in Comparison, The US Supreme Court and the German Federal Contituional Court, Berghahn Books, New York-Oxford, 2002.

Satjipto Rahardjo, Ilmu Hukum, Penerbit PT. Citra Aditya Bakti, Bandung 2000.

Tom Ginsburg,Judicial Review In New Democracies, Constitutional Court in Asian Cases, Cambridge University Press 2003.

Undang-Undang Dasar 1945

Panduan Dalam Memasyarakatkan Undang-Undang Dasar Negara Republik Indonesia Tahun 1945, Latar Belakang, Proses Dan Hasil Perubahan Undang-Undang Dasar Negara Republik Indonesia Tahnun 1945, Sekretariat Jenderal MPR R.I. 2003 